\title{
Composition of the board of directors and pay-performance sensitivity ${ }^{\star}$
}

\author{
Isac de Freitas Brandão ${ }^{1}$ \\ (D) https://orcid.org/0000-0002-4928-8637 \\ Email: isac.freitas@ifce.edu.br \\ Alessandra Carvalho de Vasconcelos ${ }^{2}$
(D) https://orcid.org/0000-0002-6480-5620
Email: alessandra.vasconcelos@ufc.br \\ Márcia Martins Mendes De Luca² \\ (D) https://orcid.org/0000-0002-9995-5637 \\ Email: marciammdeluca@gmail.com \\ Vicente Lima Crisóstomo² \\ (D) https://orcid.org/0000-0002-8593-0471 \\ Email:vlc@ufc.br
}

\begin{abstract}
${ }^{1}$ Universidade Federal do Ceará, Faculdade de Economia, Administração, Atuária e Contabilidade, Programa de Pós-Graduação em Administração e Controladoria, Fortaleza, CE, Brazil

${ }^{2}$ Universidade Federal do Ceará, Faculdade de Economia, Administração, Atuária e Contabilidade, Departamento de Contabilidade, Fortaleza, CE, Brazil
\end{abstract}

Received on 09.25.2017 - Desk acceptance on 10.19.2017 - $3^{\text {rd }}$ version approved on 02.11.2018 - Ahead of print on 09.03.2018 Ad Hoc Associate Editor: Josete Florêncio dos Santos

\begin{abstract}
This article investigates, in the Brazilian capital market, the effect of the composition of the board of directors on executive compensation sensitivity to market performance, known as pay-performance sensitivity (PPS). Due to potential agency conflicts between controlling and minority shareholders and between shareholders and managers, members of the board of directors of the executive board or those appointed by the controlling shareholder might have less independence, something which may compromise monitoring effectiveness and, consequently, reduce the PPS. The purpose is contributing to understand the agency conflicts that have taken place in the Brazilian capital market and to define the configuration of the monitoring and compensation mechanisms that minimize total agency costs, maximizing shareholders' wealth. The research results have implications for understanding the agency relations and for corporate governance in the Brazilian capital market. It is concluded that the relation between the monitoring exercised by the board of directors and executive compensation is a condition for its effectiveness as a governance mechanism in the Brazilian capital market. Data within the period 2013-2015 from 92 companies that participate in the Brazil 100 Index (IBRX 100) of the São Paulo Stock, Mercantile \& Futures Exchange (BM\&FBOVESPA) were analyzed. In addition to tests of difference between mean values and correlation, estimates were processed through feasible generalized least squares modeling. The independence of the board of directors vis-à-vis the controlling shareholder and the executive board may work as a corporate governance mechanism supplementing executive compensation. The results of this study indicate that the proportion of executives and independent members in the board of directors reduces the PPS, a measurement for executive compensation effectiveness made operational by the contemporary relation between increased managers' compensation and increased company's market value.
\end{abstract}

Keywords: agency conflicts, corporate governance, board of directors, executive compensation, pay-performance sensitivity.

Correspondence address

Isac de Freitas Brandão

Universidade Federal do Ceará, Programa de Pós-Graduação em Administração e Controladoria

Avenida da Universidade, 2846 - CEP 60020-180

Benfica - Fortaleza - CE - Brazil

*Paper presented at the XI ANPCONT Congress, Belo Horizonte, MG, Brazil, June 2017. 


\section{INTRODUCTION}

Executive compensation is pointed out as one of the agency costs incurred by shareholders, as a result of conflicts between their interests and managers' interests (Bebchuk \& Fried, 2003; Jensen \& Meckling, 1976). This cost may be an instrument to align interests, by encouraging managers to make decisions that maximize return for shareholders (Correia, Amaral \& Louvet, 2014; Murphy, 1998). In this context, the optimal executive compensation contract might be the one that maximizes compensation sensitivity to corporate performance (Murphy, 1998). The financial literature addresses such sensitivity, in general, as the relation between increased managers' compensation and increased company's market value, termed as pay-performance sensitivity (PPS) (Jensen \& Murphy, 1990; Murphy, 1998; Víctor, 2013). However, if there are no control mechanisms over managers' actions, they can earn a value higher than the return provided by their actions to the shareholders, reducing the PPS (Hassen, Ouakdi \& Omri, 2015).

In Brazil, the administrators' compensation, including members of the board of directors and executive board, is fixed by the shareholders' general meeting, according to Law No. 6,404 (1976), enacted on December 15, 1976, the Brazilian Corporation Law. According to the Brazilian Institute of Corporate Governance (IBGC, 2015), the board of directors is the body responsible for defining executive compensation policy, while the general meeting must approve it. In this context, a rather active and independent board of directors might seek the optimal executive compensation contract that can make it possible to maximize the PPS (Core, Holthausen \& Larcker, 1999; Víctor, 2013).

This issue led to the following question:

What is the effect of the composition of the board of directors on executive compensation sensitivity to corporate performance?

This research aimed to investigate the effect of the composition of the board of directors on the executive board compensation sensitivity to performance in Brazilian companies.

In countries with an Anglo-Saxon corporate governance model (Rossetti \& Andrade, 2012), research was conducted on the correlation between the composition of the board of directors and the effectiveness of executive compensation (Chhaochharia \& Grinstein, 2009; Conyon, 1997; Core et al., 1999; Lippert \& Moore, 1994; Lippert \& Porter, 1997). In these countries, most companies have a dispersed ownership structure, characterizing the agency conflict between shareholders and managers and there is greater effectiveness of external control mechanisms (La Porta, Lopez-de-Silanes, Shleifer \& Vishny, 1998).

In the Brazilian market, characterized by companies with high ownership concentration, poor enforcement, and weak legal protection of minority shareholders (La Porta et al., 1998), there has been an effort to improve corporate governance standards, with actions such as differential listing segments on the São Paulo Stock, Mercantile \& Futures Exchange (BM\&FBOVESPA) and stimulating the purchase of shares by institutional investors (Black, Carvalho \& Sampaio, 2014; Blume \& Alonso, 2007), making the capital market stronger. These characteristics highlight the importance of investigating this correlation in Brazilian companies. The predominant agency conflict in Brazil lies on the relation between controlling shareholder, who has excess power over management, and minority shareholders (Brandão \& Crisóstomo, 2015; Claessens \& Yurtoglu, 2013), something which may reduce the independence of the board of directors. The lower pressure from the capital market and the legal system for optimization of corporate governance systems in the Brazilian capital market raises the importance of internal corporate governance mechanisms (Claessens \& Yurtoglu, 2013), such as the board of directors.

Due to potential agency conflicts between controlling and minority shareholders and between shareholders and managers, members of the board of directors who are members of the executive board or those appointed by the controlling shareholder would have less independence, something which may compromise monitoring effectiveness and, consequently, reduce the PPS. Therefore, the study, tests the hypothesis that "the composition of the board of directors affects executive compensation sensitivity to corporate performance."

With this research, it is hoped to further base corporate governance as a field of study in Brazil, by analyzing the correlation between monitoring mechanisms (composition of the board of directors) and managers' compensation (executive compensation) and the effectiveness of this correlation in maximizing return for shareholders (compensation sensitivity to performance). Thus, the aim is contributing to understand the agency conflicts that have taken place in the Brazilian capital market and to define the configuration of the monitoring and 
compensation mechanisms that minimize total agency costs, maximizing return for shareholders.

Data within the period from 2013 to 2015 belonging to 92 companies that participate in the Brazil 100 Index (IBRX 100) of the BM\&FBOVESPA were analyzed. Corporate performance was measured in terms of annual variation in the market value. Executive compensation was measured by the increase in total annual and per capita annual pay. In the board of directors, the following items were identified: the proportion of effective members participating in the executive board, the proportion of effective members appointed by minority shareholders, the proportion of effective members declared independent, and the existing overlap between the functions chief executive officer (CEO) and chairman of the board of directors. The effect of the composition of the board of directors on executive compensation sensitivity was analyzed by means of difference test between mean values, correlation analysis, and regression analysis.

\section{LITERATURE REVIEW AND HYPOTHESES}

\subsection{Agency Conflicts and Executive Compensation}

The agency theory analyzes conflicts of interest between shareholders (principal) and managers (agent) with a focus on the separation of ownership and management (Jensen $\&$ Meckling, 1976). These conflicts generate agency costs that might reduce the principal's well-being: monitoring expenses and managerial incentives by the principal; expenses with the granting of contractual guarantees by the agent; and residual costs resulting from managers' actions that do not maximize the principal's well-being.

Among the amounts spent by the principal, Jensen and Meckling (1976) include applying appropriate incentives to the agent. Shleifer and Vishny (1997) argue that long-term contractual incentives for managers are the best solution to align their interests with shareholders' interests. Overt incentives for the alignment of interests between managers and shareholders concern managers' compensation (Tirole, 2006).

According to Murphy (1998), compensation plans are designed to align risk aversion interests and executives' interests with shareholders' interests. According to the theory of the optimal compensation contract (Hart \& Holmstrom, 1986), the best executive compensation configuration is the one maximizing the neutral risk of the shareholder's purpose measured by the difference between corporate performance and cost of managers' compensation. Based on the information principle (Holmstrom, 1979), the best measurement for manager performance in terms of maximizing shareholder's wellbeing is based on stock prices.

Thus, the compensation policy effectiveness has been investigated through executive compensation sensitivity to corporate performance, known as PPS (Jensen \& Murphy, 1990). The model proposed by Jensen and Murphy
(1990), more commonly used in empirical research (Murphy, 1998; Víctor, 2013), investigates the increase of each monetary unit in executive compensation for each thousand monetary units in the market value. Some studies use other measurements for market performance or book return and total or per capita pay for executive compensation (Murphy, 1998; Víctor, 2013). In Brazil, empirical evidence shows inconsistent results about the correlation between executive compensation and corporate performance (Correia et al., 2014; Fernandes \& Mazzioni, 2015; Krauter, 2013; Sonza \& Kloeckner, 2014).

\subsection{Board of Directors and Pay-Performance Sensitivity}

In order to make the compensation policy capable to align managers' interests with shareholders' interests, other internal governance mechanisms are needed (Correia et al., 2014). In firms with a weaker governance structure, more agency problems occur and managers have more discretionary power to influence their own compensation (Kerr \& Kren, 1992).

The Brazilian legislation assigns to the general meeting of shareholders the role of determining the remuneration of board of directors and executive board. According to the IBGC (2015), the board of directors must define the compensation policy and incentives for the executive board as a whole, as well as evaluate its performance. Good corporate governance practices for Brazilian companies even highlight the importance of having an advisory committee for the board of directors, preferably consisting of independent directors, responsible for appointing executives and defining the executives' compensation policy (IBGC, 2015). When exercising this function, executives may use their bargaining power along with members of the board of directors to maximize its 
usefulness, leading to a compensation policy that does not maximize value for external shareholders (Bebchuk \& Fried, 2003; Core et al., 1999). More recently, the research by Aguiar and Pimentel (2017) found evidence of a bidirectional relation between executive compensation and financial and market performance, but it did not analyze the effect of the composition of the board of directors on this relation.

O’Reilly and Main (2007) see strong indications that the greater the number of board members appointed by the CEO, the lesser the compensation contract resembles something negotiated on a fairly basis. Bruce and Skovoroda (2015) believe that the executives' ability to influence their compensation is greater when the board of directors is weak and executives are strong. According to these authors, the separation between the role of CEO and the chairman of the board of directors, the greater proportion of non-executive members in this board, and the effectiveness and independence of the nominating and compensation committees are associated with a rather robust compensation process.

The literature on the effect of the board of directors' composition on the PPS is still incipient in Brazil. One of the few studies found (Víctor, 2013) investigated this correlation in the context of company obligation to disclose information about its executives' compensation. The author used the number of external members appointed by the controlling shareholder as a characteristic of the board of directors and the change in the natural logarithm of the average compensation of the board of directors and of the executive board as a variable indicating managers' compensation. The research sample was composed by Brazilian companies and a control group consisting of U.S. companies. The findings indicated that, when a distinction is made between Brazilian and U.S. companies (by means of a dummy variable), a higher percentage of external members reduces the PPS in Brazilian companies. However, when no distinction was made, no effect was observed for the composition of the board of directors on the PPS.

\subsection{Development of Specific Hypotheses and the Theoretical Model}

Considering the purpose of this study, four hypotheses were formulated regarding the composition of the board of directors that can influence the increase or decrease in agency conflicts and interfere with the PPS.

The power and locus of control of the company CEO increase by accumulating the position of chairman of the board of directors, whereas an independent chairman makes it easier to evaluate the executive board on an objective basis (Boyd, 1994). Therefore, it is expected that accumulating of the position of company CEO with that of chairman of the board of directors, known as the CEO duality, reduces the compensation policy effectiveness due to the CEO's attempt to reduce its risk (Krause, Semadeni \& Cannella, 2014), something which might lead to reduce the PPS. It is worth noticing that some studies conducted in the U.S. and British markets did not find empirical evidence of this correlation (Conyon, 1997; Lippert \& Porter, 1997).

$\mathrm{H}_{1}$ : the CEO duality reduces the executive compensation sensitivity to performance.

Fama and Jensen (1983) suggest that non-executive members of board of directors are more active in monitoring than insiders. The presence of company executives in the board of directors may help raise their power of influence on this board, making it more difficult for executives to move out in case of underperformance (Sonza \& Kloeckner, 2014). Likewise, a larger number of executives in its board of directors can reduce the PPS (Lippert \& Porter, 1997).

$\mathrm{H}_{2}$ : the greater proportion of executives in the board of directors reduces the executive compensation sensitivity to performance.

Unlike what takes place in the Anglo-Saxon environment, where the main agency conflict lies on the relation between shareholders and managers, companies with a controlling shareholder predominate in Brazil, something which gives rise to another agency conflict, derived from the relation between the controlling shareholder and minority shareholders, termed as principal-principal agency conflict (Brandão \& Crisóstomo, 2015; Claessens \& Yurtoglu, 2013). In this context, the board of directors mostly consists of members appointed by the controlling shareholder, and this also influences the nomination of managers (Young, Peng, Ahlstrom, Bruton \& Jiang, 2008). This overlap between controlling shareholder and management may generate, as private benefits of control, earnings that do not correspond to managers' actions. For a more effective performance of the board of directors in this context, the presence of members representing the position of minority shareholders in this collegiate is key.

$\mathrm{H}_{3}$ : the greater proportion of members of the board of directors not appointed by the controlling shareholder increases the executive compensation sensitivity to performance. 
In addition to the external members and those not indicated by the controlling shareholder, there are, in the board of directors, independent members who, according to the Brazilian legislation, should not have any relation to shareholders or managers, and this may mitigate both conflicts between shareholders and managers and those between the controlling shareholder and minority shareholders. A board of directors with greater proportion of independent members (Chhaochharia \& Grinstein, 2009; Core et al., 1999) and advised by an independent compensation committee (Guthrie, Sokolowsky \& Wan, 2012) may reduce executive power, by increasing the PPS (Ozerturk, 2005).

$\mathrm{H}_{4}$ : the greater proportion of independent members in the board of directors increases the executive compensation sensitivity to performance.

Figure 1 represents the study's theoretical model, which synthesizes the relations expected having the four hypotheses formulated as a basis.

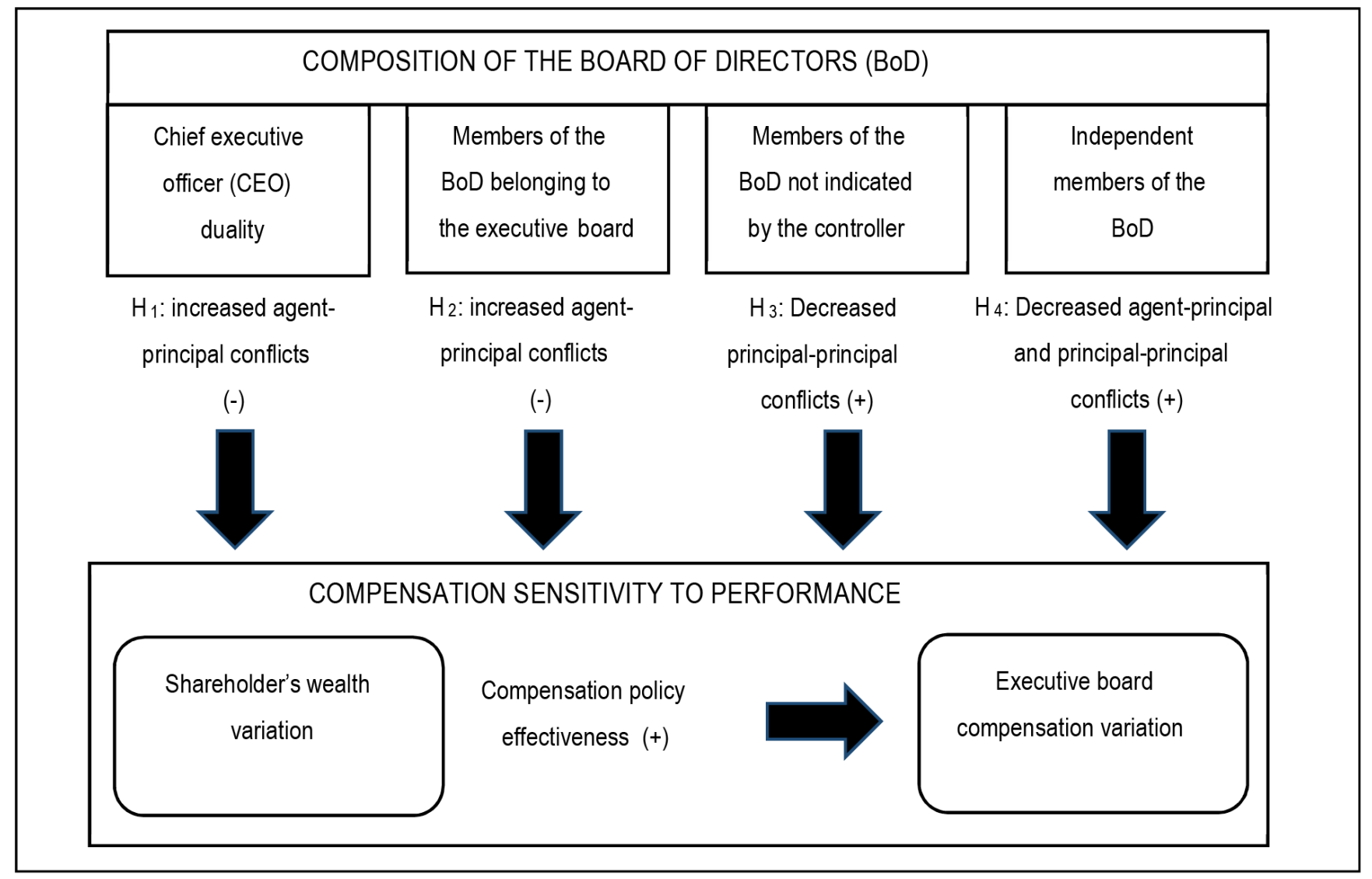

Figure 1 Research's theoretical model

Source: Prepared by the authors.

The hypotheses $\mathrm{H}_{1}$ and $\mathrm{H}_{2}$ refer to conflicts between shareholders and managers arising from the presence of executives in the board of directors, which increases the risk of expropriation by managers (agent-principal conflict): overlap between the positions of company CEO and chairman of the board of directors (CEO duality) and company executives in the board of directors. The hypothesis $\mathrm{H}_{3}$ addresses the participation of members of the board of directors not indicated by the controlling shareholder, which might reduce conflicts between the latter and minority shareholders (principal-principal conflict). The hypothesis $\mathrm{H}_{4}$ addresses the presence of independent members in the board of directors, something which might reduce agency conflicts, both from the agentprincipal perspective and from the principal-principal perspective. 


\section{METHODOLOGY}

\subsection{Sample and Data Source}

The research population includes the 100 companies whose stocks constitute the IBRX 100 of the BM\&FBOVESPA, theoretical portfolio of assets with the highest tradability and representativeness in the Brazilian stock market. The choice of this group was mainly due to the need to use, as a measurement for performance, company's market value via stock prices, which requires minimum criteria for tradability. Also, the IBRX 100 companies are those most representative of the Brazilian capital market. We chose to analyze data from the last three fiscal years available at the date of survey (2013, 2014, and 2015).

Data were collected from companies whose stocks comprised the theoretical portfolio of the IBRX 100 within the period from September to December 2016, totaling 97 companies ( 3 companies had 2 stocks in the IBRX 100). With the exclusion of 5 companies that did not have all data required by the survey, the sample consisted of an unbalanced panel with 92 companies and 272 observations.

Data on the composition of the board of directors were extracted from the company's Reference Forms, available on the website of the Brazilian Securities and Exchange Commission (CVM). Executive compensation data were extracted from the Brazilian Corporate Information System (SInC) and financial data were collected from the Economatica ${ }^{\circledR}$ database.

\subsection{Empirical Model}

The empirical model on which this study was based is the PPS model as proposed by Jensen and Murphy (1990), which regressed the increase in each monetary unit in the CEO compensation to the increase in every 1,000 monetary units in the market value of U.S. companies. The choice of market value as a performance variable is related to the information principle (Holmstrom, 1979), according to which the best measurement for manager performance in terms of maximizing shareholder's well-being is based on stock prices. The use of compensation and market value variation instead of global values contributes to mitigate endogeneity problems due to explanatory variables omitted (Hallock, Madalozzo \& Reck, 2010).

The empirical model of this research adds, to the model proposed by Jensen and Murphy (1990), the variables indicating the composition of the board of directors and an interactive variable of market value variation (in thousands of reais) with the variables indicating the composition of the board of directors, as well as a set of control variables, as observed in equation 1 .

$$
\Delta C O M_{i, t}=\alpha+\beta_{1} \Delta M V_{i, t}+\beta_{2} C O M P B D_{i, t}+\beta_{3} \Delta M V_{i, t} * C O M P B D_{i, t}+\beta_{4} \sum_{i, t} \operatorname{CONT}+1
$$

where $\Delta \mathrm{COM}_{\mathrm{i}, \mathrm{t}}$ is executive board compensation variation of company $i$ in period $t$ in relation to period $t-1, \Delta \mathrm{MV}_{\mathrm{i}, \mathrm{t}}$ is the variation, in thousands of reais, of the market value of company $i$ in period $t$ in relation to period $t-1, \mathrm{COMPBD}_{\mathrm{i}, \mathrm{t}}$ represents the variables indicating the composition of the board of directors of company $i$ in period $t, \Sigma C O N T_{i t}$ is the vector of control variables included in the model, $\beta_{1}$, $\beta_{2}$ and $\beta_{3}$ and $\beta_{4}$ are the angular coefficients of explanatory variables, and $\varepsilon$ is the error term in the equation.

It is worth highlighting the value and statistical significance of the coefficient of the interaction variable $\left(\beta_{3}\right)$, which measures the moderating effect of the composition variables of the board of directors on the PPS, as indicated by Hair, Anderson, Tathan and Black (2005). If $\beta_{3}$ is statistically different from 0 , the hypothesis that the composition of the board of directors affects compensation sensitivity to performance $\left(\beta_{1}\right)$ is accepted.

\subsection{Measurement of Variables}

Table 1 summarizes the operationalization of the study variables. The variable executive board compensation ( $\triangle \mathrm{COM}$ ), unlike what Jensen and Muphy (1990) propose, was operationalized in terms of the total compensation of the executive board, considering the sum of the executives' compensation $(\triangle \mathrm{TCOM})$ and the per capita pay $(\triangle \mathrm{PCCOM})$ weighted by company's market value in $t$ - 1 . In the original model, CEO compensation was used. Market value variation $(\triangle M V)$ has been made operational in a similar way to what was proposed by Jensen and Murphy (1990), considering the total variation in company's market value in thousands of reais, also weighted by market value in $t-1$. Weighting was due to the high amplitude of original data. 
Table 1

Variables used in the study

\begin{tabular}{|c|c|c|c|c|}
\hline Construct & Variable & Operationalization & Data source & References \\
\hline \multirow{2}{*}{$\begin{array}{l}\text { Executive board } \\
\text { compensation } \\
\text { variation } \\
(\triangle \mathrm{COM})\end{array}$} & $\begin{array}{l}\text { Total compensation } \\
\text { variation }(\triangle \mathrm{TCOM})\end{array}$ & $\begin{array}{c}\text { Difference between total executive } \\
\text { board compensation in } t \text { and } t \text { - } 1 \text { (in } \\
\mathrm{R} \$ \text { units) weighted by market value in } \\
t-1 \text { (in thousand } \mathrm{R} \$ \text { ) }\end{array}$ & $\begin{array}{l}\text { Reference Form, } \\
\text { item 13.2, SInc }\end{array}$ & $\begin{array}{c}\text { Jensen and Murphy (1990) } \\
\text { Víctor (2013) }\end{array}$ \\
\hline & $\begin{array}{c}\text { Per capita pay variation } \\
(\triangle \mathrm{PCCOM})\end{array}$ & $\begin{array}{l}\text { Difference between per capita } \\
\text { executive board compensation in } t \\
\text { and compensation in } t-1 \text { (in } \mathrm{R} \$ \text { units) } \\
\text { weighted by market value in } t-1 \text { (in } \\
\text { thousand } \mathrm{R} \$ \text { ) }\end{array}$ & $\begin{array}{l}\text { Reference Form, } \\
\text { item 13.2, via } \operatorname{SInC}\end{array}$ & $\begin{array}{c}\text { Jensen and Murphy (1990) } \\
\text { Víctor (2013) }\end{array}$ \\
\hline $\begin{array}{l}\text { Performance } \\
\quad(\Delta \mathrm{MV})\end{array}$ & $\begin{array}{l}\text { Market value variation } \\
\qquad(\Delta M V)\end{array}$ & $\begin{array}{l}\text { Difference between company's market } \\
\text { value in } t \text { and value in } t-1 \text { (in thousand } \\
\mathrm{R} \$ \text { ) weighted by market value in } t-1 \text { (in } \\
\text { thousand } R \$ \text { ) }\end{array}$ & Economatica $^{\circledR}$ & Jensen and Murphy (1990) \\
\hline \multirow{4}{*}{$\begin{array}{l}\text { Composition } \\
\text { of the BoD } \\
\text { (COMPBD) }\end{array}$} & CEO duality (DUALBD) & $\begin{array}{l}\text { Accumulation of positions of CEO and } \\
\text { chairman of the BoD (dummy variable) }\end{array}$ & $\begin{array}{l}\text { Reference Form, } \\
\text { item } 12.6 / 8\end{array}$ & $\begin{array}{l}\text { Conyon, (1997) } \\
\text { Lippert and Porter (1997) }\end{array}$ \\
\hline & $\begin{array}{l}\text { Members of the BoD } \\
\text { participating in the } \\
\text { executive board (INTBD) }\end{array}$ & $\begin{array}{l}\text { Proportion of effective members of } \\
\text { the BoD that hold an executive board } \\
\text { position }\end{array}$ & $\begin{array}{l}\text { Reference Form, } \\
\text { item } 12.6 / 8\end{array}$ & Lippert and Porter (1997) \\
\hline & $\begin{array}{l}\text { Minority members of the } \\
\text { BoD (MINBD) }\end{array}$ & $\begin{array}{l}\text { Proportion of effective members of the } \\
\text { BoD not indicated by the controlling } \\
\text { shareholder }\end{array}$ & $\begin{array}{l}\text { Reference Form, } \\
\text { item } 12.6 / 8\end{array}$ & Víctor (2013) \\
\hline & $\begin{array}{l}\text { Independente members of } \\
\text { the BoD (INDBD) }\end{array}$ & $\begin{array}{l}\text { Proportion of members of the BoD } \\
\text { regarded as independent }\end{array}$ & $\begin{array}{l}\text { Reference Form, } \\
\text { item } 12.6 / 8\end{array}$ & $\begin{array}{l}\text { Chhaochharia and Grinstein } \\
\text { (2009) }\end{array}$ \\
\hline \multirow{6}{*}{$\begin{array}{l}\text { Control } \\
\text { variables } \\
(\mathrm{CONT})\end{array}$} & $\begin{array}{c}\text { Compensation committee } \\
\text { (COMPCOM) }\end{array}$ & $\begin{array}{l}\text { Presence of a compensation committee } \\
\text { in the BoD (dummy variable) }\end{array}$ & $\begin{array}{l}\text { Reference Form, } \\
\text { item } 12.1\end{array}$ & Guthrie et al. (2012) \\
\hline & Return on equity (ROE) & $\begin{array}{l}\text { Ratio between company's net income } \\
\text { in } t \text { and the company's equity in } t-1\end{array}$ & Economatica $^{\circledR}$ & Aguiar and Pimentel (2017) \\
\hline & $\begin{array}{l}\text { Size } \\
\text { (SIZE) }\end{array}$ & $\begin{array}{l}\text { Natural logarithm of total company } \\
\text { assets in } t-1\end{array}$ & Economatica $^{\circledR}$ & Aguiar and Pimentel (2017) \\
\hline & $\begin{array}{l}\text { Concentration of voting } \\
\text { rights (OWNER) }\end{array}$ & $\begin{array}{c}\text { Percentage of ordinary shares held } \\
\text { by the company's three biggest } \\
\text { shareholders in } t\end{array}$ & Economatica $^{\circledR}$ & Correia et al. (2014) \\
\hline & Activity sector (SECTOR) & $\begin{array}{l}\text { Company's activity sector according to } \\
\text { the Economatica }{ }^{\circledR} \text { (dummy variable) }\end{array}$ & Economatica $^{\circledR}$ & Aguiar and Pimentel (2017) \\
\hline & Time period (YEAR) & Year of observation (dummy variable) & - & - \\
\hline
\end{tabular}

$B O D=$ Board of Directors; $C E O=$ chief executive officer.

Source: Prepared by the authors.

The composition of the board of directors (COMPBD) has been made operational in four proxies, one for each specific hypothesis, considering only the effective members of the board of directors: CEO duality (DUALBD); proportion of effective members of the board of directors who hold an executive board position (INTBD); proportion of effective members of the board of directors not indicated by the controlling shareholder (MINBD); and proportion of members of the board of directors regarded as independent (INDBD).

Control variables included as potential determinants of executive compensation: the existence of a compensation committee linked to the board of directors (COMPCOM), responsible for supervising the conception and implementation of the executive annual incentive plan
(Machado \& Beuren, 2015); return on equity (ROE) as a proxy for financial performance (Aguiar \& Pimentel, 2017); size of the company (SIZE) approximated by the natural logarithm of the total assets (Aguiar \& Pimentel, 2017); concentration of voting rights in the three biggest shareholders (OWNER) (Correia et al., 2014); activity sector (SECTOR) (Aguiar \& Pimentel, 2017); and year of observation (YEAR).

\subsection{Statistical Procedures}

The hypotheses were tested using means difference tests and estimates processed through equation 1 . The mean difference tests are aimed at comparing companies whose board of directors has, among its effective members, 
those not indicated by controlling shareholders (minority), those participating in the executive board (internal), and those declared independent, as well as the accumulation of positions of CEO and chairman of the board of directors (CEO duality). As for these four characteristics, all the metric variables $(\triangle \mathrm{TCOM}, \triangle \mathrm{PCP}, \triangle \mathrm{MV}$, SIZE, ROE, and OWNER) were compared. The Mann Whitney U test was used, given the non-normality of variables.

In the estimates, the dependent variables were total compensation variation $(\triangle \mathrm{TCOM})$ and per capita pay variation $(\triangle \mathrm{PCCOM})$. For each of the variables, an estimate was processed, using each of the four variables indicating the composition of the board of directors (DUALBD, INTBD, MINBD, and INDBD). In all estimations, feasible generalized least squares (FGLS) modeling was used to mitigate heteroscedasticity problems and autocorrelation of residues observed in regression analysis with panel data (Wooldridge, 2002).

The normality of residues was verified by means of the Kolmogorov-Smirnov test and collinearity between the independent variables was verified through the FIV statistics. Both tests in the estimates processed have shown that the assumptions were not violated.

\section{RESULTS}

\subsection{Descriptive Statistics}

Table 2 shows the descriptive statistics of the composition of the board of directors. The first part identifies the composition in absolute numbers and the second indicates the composition relativized by the total number of members.

Table 2

Descriptive statistics of the composition of the board of directors

\begin{tabular}{|c|c|c|c|c|c|c|}
\hline & Variable & Minimum & Maximum & Average & Standard deviation & $\begin{array}{c}\text { Coefficient of } \\
\text { variation }\end{array}$ \\
\hline \multirow{4}{*}{$\begin{array}{c}\text { Number of } \\
\text { members }\end{array}$} & Total & 4.00 & 17.00 & 8.60 & 2.01 & 0.23 \\
\hline & Minority & 0.00 & 11.00 & 2.50 & 2.93 & 1.17 \\
\hline & Internal & 0.00 & 6.00 & 0.68 & 0.84 & 1.23 \\
\hline & Independent & 0.00 & 8.00 & 2.35 & 1.66 & 0.71 \\
\hline \multirow{3}{*}{ Proportion } & Minority (MINBD) & 0.00 & 1.00 & 0.29 & 0.34 & 1.16 \\
\hline & Internal (INTBD) & 0.00 & 0.55 & 0.08 & 0.10 & 1.20 \\
\hline & $\begin{array}{l}\text { Independent } \\
\text { (INDBD) }\end{array}$ & 0.00 & 1.00 & 0.28 & 0.21 & 0.73 \\
\hline
\end{tabular}

Notes: the variables are described in Table 1; number of companies: 92; number of observations: 272; period under analysis: 2013 to 2015.

Source: Prepared by the authors.

The board of directors has an average of eight to nine members, with low variability of data. This figure is in accordance with the recommendations of the IBGC (2015), which suggests between five and 11 effective members. This is close to the findings reported by Cunha and Martins (2015), who investigated the companies in the IBRX 100 within the period from 2008 to 2012, finding the average composition of 8.54 members.

Regarding the composition, it is observed that $29 \%$ of the members of the board of directors are not appointed by the controlling shareholder, $8 \%$ are company executives and $28 \%$ are declared independent. An unreported temporal analysis indicates that the size and composition of the board of directors remain stable, with no statistically significant differences in the three years analyzed. Comparing studies conducted in previous periods, Brandão and Crisóstomo (2015) verified that 27\% of the members were indicated by minority shareholders, $12 \%$ were internal, and $20 \%$ were independent, in the 100 biggest companies between 2010 and 2013. Cunha and Martins (2015) identified that $22.5 \%$ of the members were appointed by minority shareholders and $30.5 \%$ were independent. In general, it is noticed that the composition of the board of directors regarding the proportion of internal, minority, and independent members has not undergone major changes in recent years. 
As for the CEO duality, this characteristic is present in only 16 observations, about $6 \%$ of the sample. This index is lower than the $15 \%$ found by Brandão and Crisóstomo (2015) and the $25 \%$ identified by Andrade, Salazar, Calegario and Silva (2009) when studying the period from 2004 to 2006. In this study, by comparing the three years surveyed, the number of companies with CEO duality fell year after year: eight in 2013, five in 2014, and three in 2015. These figures and the comparison to previous surveys show that the practice has been discontinued in companies in the Brazilian capital market. Another characteristic of the board of directors analyzed (control variable) was the presence of a compensation committee. Out of the 272 observations, this committee is present in 139 , about $51 \%$ of the sample.

Table 3 shows the descriptive statistics of executive compensation and market value at their original values $(\mathrm{R} \$$ units for compensation and thousand $\mathrm{R} \$$ for market value).

Table 3

Descriptive statistics of executive compensation and market value in gross values

\begin{tabular}{ccccccc}
\hline \multicolumn{2}{c}{ Variables } & Minimum & Maximum & Average & Standard deviation & $\begin{array}{c}\text { Coefficient of } \\
\text { variation }\end{array}$ \\
\hline \multirow{2}{*}{\begin{tabular}{c} 
Total compensation \\
\cline { 2 - 7 }
\end{tabular}} & In the period & 69,000 & $453,527,265$ & $29,990,392$ & $56,413,309$ & 1.88 \\
\hline \multirow{2}{*}{$\begin{array}{c}\text { Per capita } \\
\text { remuneration }\end{array}$} & In the period & 19,220 & $15,261,692$ & $3,397,387$ & $2,570,666$ & 0.76 \\
\hline \multirow{2}{*}{\begin{tabular}{c} 
Market value \\
\cline { 2 - 7 }
\end{tabular}} & Annual variation & $-5,577,924$ & $6,895,910$ & 343,161 & $1,396,859$ & 4.07 \\
\cline { 2 - 7 } & In the period & 386,079 & $279,978,928$ & $20,680,448$ & $40,274,047$ & 1.95 \\
\hline
\end{tabular}

Notes: total compensation and per capita pay in $R \$$ units; market value in thousand $R \$$; number of companies: 92; number of observations: 272; period under analysis: 2013 to 2015.

Source: Prepared by the authors.

The average annual pay of the executive board in the sample companies reaches about $\mathrm{R} \$ 30$ million, while the average annual per capita pay reaches $\mathrm{R} \$ 3.4$ million. Another point to notice is the average increase in annual pay, which also leads to inflation in the values within the period under analysis compared to the survey conducted by the IBGC. The executive compensation variation in the sample is low, while the annual variation is high, with a coefficient higher than 4 . The average market value of the companies under analysis amounts to about R\$20.7 million and there was a significant loss of value within the period analyzed (coefficient of variation -6.74).

Table 4 displays the descriptive statistics of financial variables and ownership structure in the way they were used in statistical analysis.

Table 4

Descriptive statistics of the metric variables used in statistical analysis

\begin{tabular}{|c|c|c|c|c|c|c|}
\hline & Minimum & Maximum & Mean & Median & Standard deviation & $\begin{array}{c}\text { Coefficient of } \\
\text { variation }\end{array}$ \\
\hline$\triangle \mathrm{TCOM}$ & -6.806 & 6.502 & 0.259 & 0.115 & 1.111 & 4.285 \\
\hline$\triangle \mathrm{PCCOM}$ & -1.710 & 1.150 & 0.036 & 0.015 & 0.239 & 6.624 \\
\hline$\Delta \mathrm{MV}$ & -0.817 & 1.385 & -0.044 & -0.059 & 0.317 & -7.168 \\
\hline SIZE & 20.504 & 27.994 & 23.300 & 23.159 & 1.533 & 0.066 \\
\hline ROE & -1.914 & 8.605 & 0.173 & 0.134 & 0.605 & 3.503 \\
\hline OWNER & 0.069 & 1.000 & 0.599 & 0.630 & 0.235 & 0.393 \\
\hline
\end{tabular}

Notes: the variables are described in Table 1; unbalanced panel of 92 companies; number of observations: 272; period under analysis: 2013 to 2015.

Source: Prepared by the authors.

As shown in Table 3, while executive compensation increased year-over-year within the period under analysis, the market value of companies under analysis has decreased. The financial performance measured by the ROE was positive on average, but it showed great dispersion in the sample. The concentration of voting rights is high and, like size, it shows low variation in the sample.

\subsection{Composition of the Board of Directors and Pay-Performance Sensitivity}

In Table 5, the metric variables are compared to the categories of directors analyzed in the survey: minority, internal, independent, and CEO, occupying the position of chairman of the board of directors. The presence 
of these categories of board of directors' members (directors) was not associated with the executive compensation variation and the performance measured by the ROE.

Table 5

Composition of the board of directors and metric variables

\begin{tabular}{|c|c|c|c|c|c|c|c|}
\hline Board of directors & $\mathbf{n}$ & $\triangle \mathrm{TCOM}$ & $\triangle \mathrm{PCCOM}$ & $\Delta \mathrm{MV}$ & SIZE & ROE & OWNER \\
\hline Without minority members & 89 & 0.285 & 0.048 & -0.069 & 23.415 & 0.231 & 0.665 \\
\hline With minority members & 183 & 0.246 & 0.030 & -0.032 & 23.244 & 0.144 & 0.566 \\
\hline Mann Whitney's U (Z test) & & -0.170 & -0.707 & -0.550 & -0.803 & -0.688 & $-3.268 * * *$ \\
\hline Without internal members & 136 & 0.285 & 0.026 & -0.005 & 23.010 & 0.215 & 0.590 \\
\hline With internal members & 136 & 0.246 & 0.046 & -0.084 & 23.590 & 0.131 & 0.608 \\
\hline Mann Whitney's U (Z test) & & -0.980 & -0.658 & $-1.696^{*}$ & $-2.095 * *$ & -0.378 & -0.544 \\
\hline Without independent members & 50 & 0.418 & 0.065 & -0.067 & 24.368 & 0.128 & 0.747 \\
\hline With independent members & 222 & 0.223 & 0.009 & -0.039 & 23.060 & 0.183 & 0.565 \\
\hline Mann Whitney's U (Z test) & & -0.800 & -0.501 & -0.619 & $-5.329 * * *$ & -2.143 & $-4.973 * * *$ \\
\hline Without CEO duality & 256 & 0.231 & 0.031 & -0.035 & 23.275 & 0.179 & 0.601 \\
\hline With CEO duality & 16 & 0.712 & 0.119 & -0.186 & 23.699 & 0.074 & 0.555 \\
\hline Mann Whitney's U (Z test) & & -0.419 & -0.835 & $-1.916^{*}$ & -1.114 & -1.572 & -1.063 \\
\hline
\end{tabular}

Notes: unbalanced panel of 92 companies; number of observations: 272; period under analysis: 2013 to 2015; Mann Whitney U tests for independent samples.

CEO = chief executive officer.

$*, * *, * * *=$ statistical significance of 10,5 , and $1 \%$, respectively.

Source: Prepared by the authors.

Directors not indicated by the controlling shareholder are present in $67 \%$ of the observations and they are associated with lower concentration of voting rights. Controlling shareholders, when they have greater voting power, indicate all members of the board of directors, something which can maximize agency problems with minority shareholders.

Half of the companies have executives present in the board of directors and, in 6\%, the CEO accumulates the position of chairman in this board. These characteristics are associated to greater decrease in market value, corroborating Silveira, Barros and Famá (2003). The presence of executives in the board of directors is also associated with larger companies.

In $82 \%$ of the companies the presence of independent directors was verified, which is associated with smaller companies and with lower concentration of voting rights. Just as in the case of board of directors' members not appointed by the controlling shareholder, the absence of independent directors in companies having a high concentration of voting rights may aggravate agency problems between controlling and minority shareholders.

Table 6 displays the Pearson's correlation matrix between the metric variables included in the regression analysis. Although some variables do not follow a normal distribution, the normality assumption may be relaxed as the sample grows (Brooks, 2014). The two variables indicating executive board compensation, used in the estimations as dependent variables, are the only variables with a high correlation, something which could lead to collinearity problems.

Table 6

Correlation matrix between metric variables

\begin{tabular}{|c|c|c|c|c|c|c|c|c|}
\hline & $\Delta \mathrm{TCOM}$ & $\triangle \mathrm{PCCOM}$ & $\Delta \mathrm{MV}$ & MINBD & INTBD & INDBD & SIZE & ROE \\
\hline$\triangle \mathrm{PCCOM}$ & $0.81 * * *$ & & & & & & & \\
\hline$\Delta \mathrm{MV}$ & $0.14^{* *}$ & $0.11^{*}$ & & & & & & \\
\hline MINBD & -0.06 & -0.06 & 0.05 & & & & & \\
\hline INTBD & 0.09 & 0.04 & -0.09 & 0.01 & & & & \\
\hline INDBD & $-0.17^{* * *}$ & $-0.16^{* * *}$ & -0.01 & $0.42^{* * *}$ & -0.09 & & & \\
\hline SIZE & -0.04 & -0.04 & -0.03 & $-0.21^{* * *}$ & $0.15^{* *}$ & $-0.31^{* * *}$ & & \\
\hline ROE & 0.06 & -0.03 & $-0.12 *$ & -0.02 & -0.05 & -0.01 & $-0.10^{*}$ & \\
\hline OWNER & -0.04 & 0.00 & -0.05 & $-0.52^{* * *}$ & 0.09 & $-0.39 * * *$ & $0.32^{* * *}$ & 0.04 \\
\hline
\end{tabular}

Notes: the variables are described in Table 1; unbalanced panel of 92 companies; number of observations: 272; period under analysis: 2013 to 2015; Pearson's correlation coefficient between the metric variables.

$*, * *, * * *=$ statistical significance of 10,5 , and $1 \%$, respectively.

Source: Prepared by the authors. 
The proportion of directors not indicated by the controlling shareholder is not correlated to the executive compensation variation nor to the market value variation. The proportion of executives who are also directors shows a positive correlation to the total compensation variation. Meanwhile, the proportion of independent directors is negatively correlated to the variation in total compensation and in per capita pay and to the market value variation. Corroborating the Mann Whitney $U$ tests displayed in Table 5 , there is a negative correlation between the percentage of directors not indicated by controllers and independent directors and the concentration of voting rights.

Table 7 shows the result of estimates, having as dependent variables the variation in total compensation and in per capita pay, respectively, in panels A and B.

The positive correlation between market value variation and the executive board compensation variation, according to the results of estimates 1 and 7, indicates the existence of executive compensation sensitivity to performance, both in terms of total compensation variation and in terms of per capita pay variation. The inclusion of variables indicating the composition of the board of directors and the interactive variables increases the models' significance (estimates 2 to 6 and 8 to 12), indicating that the composition of the board of directors affects the PPS (Hair et al., 2005).

Regarding total compensation (Panel A), the proportion of internal directors (estimates 2 and 4 ) and independent directors (estimates 2 and 5) negatively influences the
PPS. On the other hand, while executive participation increases executive compensation (estimates 2 and 4), the relation between compensation variation and the percentage of independent directors is negative (estimates 2 and 5). The proportion of directors not indicated by the controlling shareholder and the overlap between the positions of CEO and chairman, in turn, did not affect the PPS and executive compensation variation (estimates 2, 3 , and 6). In addition, the total compensation variation was negatively affected by the presence of a compensation committee (estimates 1, 3, 5, and 6) and concentration of voting rights (estimates 2, 3, and 5) and positively related to the ROE (estimates $1,3,4$, and 6). The year of observation only had statistical significance at the level of $10 \%$ in one estimation (4) and the activity sector in estimates 1, 2, 4, and 6. Size did not have a statistically significant relation in any estimate.

As for per capita pay (Panel B), the proportion of executives on the board of directors and independent directors is related to decreased per capita PPS. The percentage of independent members on the board of directors reduces compensation variation and its sensitivity to performance (estimates 8 and 11). The proportion of directors not indicated by the controlling shareholder and the overlap between the positions of CEO and chairman have a statistically significant effect on the PPS and per capita pay variation (estimates 8, 9, and 12). Except for the activity sector (estimates $8,10,11$, and 12 ), the control variables did not have statistical significance.

Table 7

Composition of the board of directors and pay-performance sensitivity

\begin{tabular}{|c|c|c|c|c|c|c|c|c|c|c|c|c|}
\hline \multirow{2}{*}{$\begin{array}{l}\text { Explanatory } \\
\text { variables }\end{array}$} & \multicolumn{6}{|c|}{$\begin{array}{c}\text { Panel A } \\
\text { Dependent variable: } \Delta \text { TCOM }\end{array}$} & \multicolumn{6}{|c|}{$\begin{array}{c}\text { Panel B } \\
\text { Dependent variable: } \triangle \text { PCCOM }\end{array}$} \\
\hline & 1 & 2 & 3 & 4 & 5 & 6 & 7 & 8 & 9 & 10 & 11 & 12 \\
\hline$\Delta \mathrm{MV}$ & $0.614 * * *$ & $1.521^{* * *}$ & $0.639^{* *}$ & $0.948^{* * *}$ & $1.083^{* * *}$ & $0.698^{* * *}$ & $0.082 *$ & $0.406^{* * *}$ & 0.091 & $0.159 * * *$ & $0.293^{* * *}$ & $0.104^{* *}$ \\
\hline MINBD & & -0.057 & -0.273 & & & & & 0.033 & -0.034 & & & \\
\hline $\mathrm{MINBD}^{*} \Delta \mathrm{MV}$ & & 0.308 & -0.126 & & & & & 0.115 & -0.036 & & & \\
\hline INTBD & & $1.176^{*}$ & & $1.505^{* *}$ & & & & 0.105 & & 0.203 & & \\
\hline INTBD* $\Delta M V$ & & $-4.570 * *$ & & $-4.586^{* *}$ & & & & $-1.143^{* * *}$ & & $-1.079 * *$ & & \\
\hline INDBD & & $-1.208^{* * *}$ & & & $-1.257^{* * *}$ & & & $-0.318^{* * *}$ & & & $-0.297^{* * *}$ & \\
\hline INDBD* $\Delta \mathrm{MV}$ & & $-2.239 * *$ & & & $-1.765^{*}$ & & & $-0.939 * * *$ & & & $-0.769 * * *$ & \\
\hline DUALBD $^{\mathrm{a}}$ & & 0.191 & & & & 0.362 & & 0.034 & & & & 0.059 \\
\hline DUALBD* $\Delta M V$ & & -1.094 & & & & -1.520 & & -0.341 & & & & $-0.430^{*}$ \\
\hline SIZE & 0.027 & -0.018 & 0.021 & 0.005 & -0.003 & 0.020 & -0.001 & -0.010 & -0.002 & -0.004 & -0.008 & -0.000 \\
\hline COMPCOM & $-0.301^{* *}$ & -0.163 & $-0.293^{* *}$ & -0.231 & $-0.236^{*}$ & $-0.260^{*}$ & -0.050 & -0.026 & -0.049 & -0.042 & -0.034 & -0.040 \\
\hline ROE & $0.195^{*}$ & 0.174 & $0.195^{*}$ & $0.224^{* *}$ & 0.150 & $0.201^{*}$ & -0.011 & -0.021 & -0.011 & -0.004 & -0.026 & -0.010 \\
\hline OWNER & -0.421 & $-0.783 * *$ & $-0.633^{*}$ & -0.502 & $-0.695 * *$ & -0.38 & -0.039 & -0.083 & -0.064 & -0.05 & -0.101 & -0.030 \\
\hline SECTOR & Yes* & Yes* & Yes & Yes* & Yes & Yes** & Yes & Yes** & Yes & Yes* & Yes* & Yes* \\
\hline YEAR & Yes & Yes & Yes & Yes* & Yes & Yes & Yes & Yes & Yes & Yes & Yes & Yes \\
\hline Wald $\chi^{2}$ & $32.22 *$ & $62.35^{* * *}$ & 33.67 & $43.47^{* *}$ & $45.83^{* * *}$ & $93.01 * *$ & 17.84 & $58.23^{* * *}$ & 18.31 & 26.24 & $39.46^{* *}$ & 25.42 \\
\hline Average FIV & 4.71 & 4.37 & 4.57 & 4.53 & 4.73 & 4.50 & 4.71 & 4.37 & 4.57 & 4.54 & 4.73 & 4.50 \\
\hline
\end{tabular}

Notes: the variables are described in Table 1; unbalanced panel of 92 companies; number of observations: 272; period under analysis: 2013 to 2015; regression analysis with feasible generalized least squares (FGLS) modeling.

$a=$ interactive variables of market value variation with the four variables indicating the composition of the board of directors (MINBD* $\triangle M V, I N T B D^{*} \triangle M V, I N D B D^{*} \triangle M V$, and DUALBD* $\triangle M V$ ).

$*, * *, * * *=$ statistical significance of 10,5 and $1 \%$, respectively.

Source: Prepared by the authors. 
Other estimates processed, such as $t$-tests and unreported robustness tests, indicate that there is PPS by analyzing the relation between $\triangle \mathrm{MV}$ lagged at one year and $\triangle \mathrm{TCOM}$ and $\triangle \mathrm{PCCOM}$. The interaction between $\triangle \mathrm{MV}$ and the variables indicating the composition of the board of directors, however, it had a lower statistical significance, keeping the same sign of the estimates in Table 7. The only interaction variable that had the highest statistical significance was DUALBD ${ }^{*} \Delta \mathrm{MV}$, with a negative effect on the PPS, but only when the dependent variable was $\triangle$ TCOM. Having in mind an opposite-to-expected effect of the variable INDBD on the PPS, estimates were calculated with $\triangle \mathrm{TCOM}$ and $\triangle \mathrm{PCCOM}$ segmented by the median and the sign of the INDBD ${ }^{*} \Delta \mathrm{MV}$ interaction variable remained unchanged. Only in one of the estimates (with $\triangle \mathrm{TCOM}$ lower than the median) the interaction variable ceased to be significant at the $10 \%$ level ( $p$ value $=0.133$ ), but the sign remained negative.

\section{DISCUSSION}

The effect of the composition of the board of directors on the PPS of those companies whose stocks were included in the IBRX 100 portfolio within the period from 2013 to 2015 was analyzed. We tested the hypotheses that the accumulation of the positions of company CEO and president of its board of directors and the proportion of executive members of the board negatively affect the PPS $\left(\mathrm{H}_{1}\right.$ and $\left.\mathrm{H}_{2}\right)$ and that the proportion of directors not appointed by the controlling shareholder and the proportion of independent members positively affect the PPS $\left(\mathrm{H}_{3}\right.$ and $\left.\mathrm{H}_{4}\right)$.

The CEO duality is seen as a measure of poor performance of the board of directors (Três, Serra \& Ferreira, 2014). In the sample companies, although the CEO duality is not often observed, the devaluation of stocks is greater than that of other companies. The estimates showed, however, that there is no influence of the CEO duality on the PPS. Thus, the study hypothesis $\mathrm{H}_{1}$ is not confirmed. Although it is regarded as a practice that increases agency disputes between shareholders and managers, there is no evidence that the position of chairman of the board of directors may be used by the $\mathrm{CEO}$ to change the executive board compensation.

The greater number of executives in the board of directors impairs the monitoring function (Boyd, 1994; Lippert \& Moore, 1994). Half of the companies have at least one executive in their board of directors, and although CEOs account for only $8 \%$ of the directors, their participation in the board of directors reduces the PPS, confirming the study hypothesis $\mathrm{H}_{2}$. On the other hand, there was a positive influence of executive participation in the total executive compensation variation, suggesting that executives, when present in the board of directors, use their influence to reduce their risk of financial loss (Lippert \& Porter, 1997), i.e. seek to dissociate their compensation from the company market performance.

Another way of analyzing the independence of a board of directors, related to agency conflicts between controlling and minority shareholders, is verifying the proportion of its members not indicated by the controlling shareholder (Brandão \& Crisóstomo, 2015). About $29 \%$ of the directors in the sample companies were not appointed by the controlling shareholder and in 33\% of the companies all the directors were appointed by the controlling shareholder. Although in a larger number than executives, no influence of the proportion of directors indicated by minority shareholders on the PPS was identified. This finding does not confirm the hypothesis $\mathrm{H}_{3}$, which predicted a positive influence. For managers of stock portfolios traded on the BM\&FBOVESPA, the directors representing minority shareholders do not influence the company strategic decisions (Bertucci, Bernardes \& Brandão, 2006), including the compensation policy.

According to IBGC (2015), independent directors are unrelated to company executives, employees, or shareholders. In the sample, independent directors account for $28 \%$ of the total and they are present in $82 \%$ of the companies. The negative correlation between the participation of independent directors and concentration of voting rights is highlighted, raising the possibility of influence of the controlling shareholder on the board of directors, something which potentiates agency problems between controlling shareholders and minority shareholders. The proportion of independent directors showed a negative influence on the PPS, not confirming the hypothesis $\mathrm{H}_{4}$, which conjectured the opposite. The executive compensation variation was also negatively affected by the proportion of independent directors. One possible explanation for this may lie on the trade off between monitoring and pay: as the board of directors becomes more independent, monitoring capacity increases, and this reduces the need for financial incentives to align the interests of managers and shareholders (Aguilera, Desender \& Castro, 2011), reducing executive compensation variation and the PPS. 


\section{CONCLUSION}

It is concluded that, in the sample companies, executive compensation sensitivity to performance is affected by the composition of the board of directors, which leads to confirmation of the general study hypothesis. Specifically, the presence of executives and independent directors is correlated to the lower PPS.

The research results have implications for understanding agency relations and for corporate governance in the Brazilian capital market. First, CEO duality is a less and less common practice in Brazilian companies, and CEO power, when he holds the position of chairman, has little influence on the executive board compensation policy. On the other hand, the greater participation of executives in the board of directors positively raises the annual variation in the total executive compensation and makes this compensation rather distant from market performance. There is a need to verify if such a detachment is only a measurement for risk aversion (Krause et al., 2014) or of the reflection of the usufruct of private benefits by the executives.
Second, the monitoring functions and executive compensation may be substitute corporate governance mechanisms (as observed in the case of independent members) or even independent ones (as in the case of directors not indicated by the controller). The effectiveness of governance practices may not be seen only cumulatively, as " the more, the better" type. One must take into account the study of the interrelation between these practices and the joint effectiveness in mitigating agency problems.

This study has limitations, highlighting the nonprobabilistic sample and the reduced analysis period, preventing the generalization of results. Further research may consider a longer period, with a probabilistic sample, and use modeling that addresses all endogeneity problems. The interrelation and joint effectiveness of executive compensation regarding other governance mechanisms, such as the concentration of voting rights and independent auditing, especially concerning the accounting information disclosed, may be investigated.

\section{REFERENCES}

Aguiar, A. B., \& Pimentel, R. C. (2017). Remuneração de executivos e desempenho no mercado brasileiro: relações contemporâneas e defasadas. Revista de Administração Contemporânea, 21(4), 545-568.

Aguilera, R. V., Desender, K., \& Castro, L. R. K. (2011). Perspectives on comparative corporate governance. In T. Clarke, \& D. Branson (Ed.), Sage handbook of corporate governance. New York: Sage.

Andrade, L. P., Salazar, G. T., Calegario, C. L. L., \& Silva, S. S. (2009, July/August). Governança corporativa: uma análise da relação do conselho de administração com o valor de mercado e desempenho das empresas brasileiras. Revista de Administração Mackenzie, 10(4), 4-32.

Bebchuk, L. A., \& Fried, J. M. (2003). Executive compensation as an agency problem. The Journal of Economic Perspectives, 17(3), 71-92.

Bertucci, J. L. O., Bernardes, P., \& Brandão, M. M. (2006). Políticas e práticas de governança corporativa em empresas brasileiras de capital aberto. Revista de Administração, 41(2) 183-196.

Black, B. S., Carvalho, A. G., \& Sampaio, J. O. (2014, September). The evolution of corporate governance in Brazil. Emerging Markets Review, 20, 176-195.

Blume, D., \& Alonso, F. (2007). Institutional investors and corporate governance in Latin America. Financial Market Trends, 2007(2), 93-131.

Boyd, B. K. (1994). Board control and CEO compensation. Strategic Management Journal, 15(5), 335-344.
Brandão, I. F., \& Crisóstomo, V. L. (2015). Concentração de propriedade e qualidade da governança da empresa brasileira. Revista Brasileira de Finanças, 13(3), 438-448.

Brooks, C. (2014). Introductory econometrics for finance (2nd ed.). Cambridge: Cambridge University Press.

Bruce, A., \& Skovoroda, R. (2015). The empirical literature on executive pay: context, the pay-performance issue and future directions [Working Paper]. High Pay Centre. Retrieved from http://highpaycentre.org/files/academic_literature_review_ FINAL.pdf

Chhaochharia, V., \& Grinstein, Y. (2009). CEO compensation and board structure. The Journal of Finance, 64(1), 231-261.

Claessens, S., \& Yurtoglu, B. B. (2013, June). Corporate governance in emerging markets: a survey. Emerging Markets Review, 15, 1-33.

Conyon, M. J. (1997). Corporate governance and executive compensation. International Journal of Industrial Organization, 15(4), 493-509.

Core, J. E., Holthausen, R. W., \& Larcker, D. F. (1999). Corporate governance, chief executive officer compensation and firm performance. Journal of Financial Economics, 51(3), 371-406.

Correia, L. F., Amaral, H. F., \& Louvet, P. (2014). Remuneração, composição do conselho de administração e estrutura de propriedade: evidências empíricas do mercado acionário brasileiro. Advances in Scientific and Applied Accounting, 7(1), 2-37. 
Cunha, A. S. L., \& Martins, O. S. (2015). Reflexo das características do conselho de administração no endividamento de companhias abertas no Brasil. Revista de Governança Corporativa, 2(1), 37-65.

Fama, E. F., \& Jensen, M. C. (1983). Separation of ownership and control. The Journal of Law and Economics, 26(2), 301-325.

Fernandes, F. C., \& Mazzioni, S. (2015). A correlação entre a remuneração dos executivos e o desempenho de empresas brasileiras do setor financeiro. Contabilidade Vista \& Revista, 26(2), 41-64.

Guthrie, K., Sokolowsky, J., \& Wan, K. M. (2012). CEO compensation and board structure revisited. The Journal of Finance, 67(3), 1149-1168.

Hair, J. F., Anderson, R. E., Tatham, R. L., \& Black, W. C. (2005) Análise multivariada de dados (5th ed.). Porto Alegre, RS: Bookman.

Hallock, K. F., Madalozzo, R., \& Reck, C. G. (2010). CEO pay-for-performance heterogeneity using quantile regression. Financial Review, 45(1), 1-19.

Hart, O., \& Holmstrom, B. (1986). The theory of contracts [Working Paper]. Massachusetts Institute of Technology. Retrieved from https://dspace.mit.edu/bitstream/ handle/1721.1/64265/theoryofcontract00hart.pdf\%3Bjs

Hassen, R. B., Ouakdi, J. El, \& Omri, A. (2015, March/April). Executive compensation and ownership structure. The Journal of Applied Business Research, 31(2), 593.

Holmstrom, B. (1979). Moral hazard and observability. The Bell Journal of Economics, 10(1), 74-91.

Instituto Brasileiro de Governança Corporativa. (2015). Código das melhores práticas de governança corporativa (5th ed.). São Paulo, SP: IBGC.

Jensen, M. C., \& Meckling, W. (1976, October). Theory of the firm: managerial behavior, agency costs and ownership structure. Journal of Financial Economics, 3(4), 305-360.

Jensen, M. C., \& Murphy, K. J. (1990). Performance pay and topmanagement incentives. Journal of Political Economy, 98(2), 225-264.

Kerr, J. L., \& Kren, L. (1992). Effect of relative decision monitoring on chief executive compensation. Academy of Management Journal, 35(2), 370-397.

Krause, R., Semadeni, M., \& Cannella, A. A., Jr. (2014). CEO duality: a review and research agenda. Journal of Management, 40(1), 256-286.

Krauter, E. (2013). Remuneração de executivos e desempenho financeiro: um estudo com empresas brasileiras. Revista de Educação e Pesquisa em Contabilidade (REPeC), 7(3), 259-273.

La Porta, R., Lopez-de-Silanes, F., Shleifer, A., \& Vishny, R. W. (1998).
Law and finance. Journal of Political Economy, 106(6), 1113-1155.

Lei n. 6.404, de 15 de dezembro de 1976. (1976, 17, December). Dispõe sobre as Sociedades por Ações. Retrieved from http:// www.planalto.gov.br/Ccivil_03/leis/L6404consol.htm

Lippert, R. L., \& Moore, W. T. (1994). Compensation contracts of chief executive officers: determinants of pay-performance sensitivity. Journal of Financial Research, 17(3), 321-332.

Lippert, R. L., \& Porter, G. (1997). Understanding CEO pay: a test of two pay-to-performance sensitivity measures with alternative measures of alignment and influence. Journal of Business Research, 40(2), 127-138.

Machado, D. G., \& Beuren, I. M. (2015). Política de remuneração de executivos: um estudo em empresas industriais brasileiras, estadunidenses e inglesas. Gestão \& Regionalidade, 31(92), 4-24.

Murphy, K. J. (1998). Executive compensation. Handbook of Labor Economics, 3(Part 2), 2485-2563.

O'Reilly, C. A., \& Main, B. G. M. (2007). Setting the CEO's pay: it's more than simple economics. Organizational Dynamics, 36(1), 1-12.

Ozerturk, S. (2005). Board independence and CEO pay. Economics Letters, 88(2), 260-265.

Rossetti, J. P., \& Andrade, A. (2012). Governança corporativa: fundamentos, desenvolvimento e tendências (6th ed.). São Paulo: Atlas.

Shleifer, A., \& Vishny, R. W. (1997). A survey of corporate governance. The Journal of Finance, 52(2), 737-783.

Silveira, A. D. M., Barros, L. A. B. C., \& Famá, R. (2003). Estrutura de governança e valor das companhias abertas brasileiras. Revista de Administração de Empresas, 43(3), 50-64.

Sonza, I. B., \& Kloeckner, G. O. (2014). A governança corporativa influencia a eficiência das empresas brasileiras? Revista Contabilidade \& Finanças, 25(65), 145-160.

Tirole, J. (2006). The theory of corporate finance. Princeton, NJ: Princeton University Press.

Três, G., Serra, F., \& Ferreira, M. P. (2014). O tempo de mandato do CEO e o desempenho das empresas: um estudo comparativo de empresas familiares e não familiares brasileiras. Revista Gestão \& Tecnologia, 14(3), 5-31.

Víctor, F. S. (2013). Estrutura de propriedade e remuneração executiva: efeitos diretos e indiretos da regulamentação (Tese de doutorado). Porto Alegre: Universidade Federal do Rio Grande do Sul.

Wooldridge, J. M. (2002). Econometric analysis of cross section and panel data. Cambridge, MA: MIT Press.

Young, M. N., Peng, M. W., Ahlstrom, D., Bruton, G. D., \& Jiang, Y. (2008). Corporate governance in emerging economies: a review of the principal-principal perspective. Journal of Management Studies, 45(1), 196-220. 